\title{
MODEL TAPER BAMBU BETUNG
}

\author{
(The Taper Model of Dendrocalamus asper Backer ex Heyne) \\ Lutfy Abdulah dan/and Sutiyono \\ Pusat Penelitian dan Pengembangan Hutan \\ Jl. Gunung Batu No. 5 Po Box 165 Bogor, Jawa Barat, Indonesia \\ Telp. 0251-8633234; Fax 0251-8638111 \\ E-mail: lutfyabdulah@yahoo.co.id; sutiyonomangunredjo@gmail.com
}

Tanggal diterima: 2 Agustus 2017; Tanggal direvisi: 22 Mei 2019; Tanggal disetujui; 3 Juni 2019

\begin{abstract}
Informations on the individual growth of bamboo stems such as dimensions of node length, node diameter, and wall-node thick are needed to increase bamboo processed yield. This study aimed to provide a model of growth estimation of individual growth of bamboo stems. Destruction method was used, and resulting data was sorted sorted by time. The correlation between age and dimensions was analyzed with cross-section technique. The results showed that there were a correlation among age with node diameter and node length, but no correlation with wall-node thick. Parameters of node length, total length of bamboo, and base node diameter significantly influenced the estimated diameter of each node. Node's sequence number, node lengths, and base node diameter can be used to compile estimation model of the bamboo wall thickness. The uniqueness of bamboo model is the importance of node sequence. This model can be used for sustainable development use of Dendrocalamus asper.
\end{abstract}

Keywords: Dendrocalamus asper, growth model, taper model

\begin{abstract}
ABSTRAK
Informasi pertumbuhan individu batang bambu seperti dimensi panjang ruas, diameter ruas, dan tebal dinding ruas bambu sangat diperlukan untuk tujuan peningkatan rendemen olahan bambu. Penelitian ini bertujuan untuk menyediakan model perangkat penduga pertumbuhan sehingga memudahkan dalam menduga pertumbuhan individu batang bambu. Metode yang digunakan adalah metode destruksi. Data yang dihasilkan diurutkan berdasarkan waktu dan selanjutnya dilakukan analisis dengan teknik cross-section sehingga dapat dibangun hubungan antara umur dengan dimensi bambu. Hasil penelitian menunjukkan bahwa ada hubungan antara umur dengan parameter diameter ruas dan panjang ruas, namun tidak dengan tebal dinding batang bambu. Parameter panjang ruas, panjang total bambu, dan diameter pada pangkal bambu berpengaruh nyata dalam menduga diameter setiap ruas. Sementara parameter nomor urut ruas, panjang ruas dan diameter pangkal dapat digunakan untuk menyusun model penduga ketebalan dinding ruas bambu. Keunikan dari model bambu ini adalah adanya parameter urutan ruas yang perlu dipertimbangkan. Model yang didapat dapat digunakan untuk penyusunan rencana pemanfaatan bambu petung secara berkelanjutan.
\end{abstract}

Kata kunci: Bambu betung, model, pertumbuhan, taper

\section{PENDAHULUAN}

Bambu merupakan jenis tanaman rerumputan dengan tingkat keragaman mencapai 1.200 jenis di seluruh dunia serta memberikan ciri yang berbeda di setiap lokasi (Sharma,Gatoo, Bock, \& Ramage, 2015). Bambu dapat tumbuh cepat, pertumbuhannya dipengaruhi faktor dominan curah hujan, suhu, dan kepadatan rumpun (Yuen, Fung, \& Ziegler, 2017). Pertumbuhan bambu 25 kali lebih cepat dari jenis cepat tumbuh tanaman hutan sehingga siklus tebangnya pada umur 3-5 tahun (Muchiri \& Muga, 2013).

Bentuk batang bambu adalah isotropic, dimana terdapat variasi serat baik secara longitudinal, tranversal, dan radial (Sharma et al., 2015). Bambu betung (Dendrocalamus asper Backer ex Heyne) memiliki diameter antara 12-15 $\mathrm{cm}$ dan bahkan sampai $20 \mathrm{~cm}$ dengan tebal dinding bambu mencapai $2 \mathrm{~cm}$ dan 
panjang ruas mencapai $60 \mathrm{~cm}$ (Salam, \& Pongen, 2008). Bambu betung memiliki ruas yang agak besar (bengkak) dengan panjang ruas pangkal lebih pendek dan panjang ruas di bagian ujung lebih panjang (Salam, \& Pongen, 2008). Kondisi ini menjadikan upaya pemanfaatan bambu betung untuk tujuan kontruksi terus dikembangkan. Sebagai contoh pembuatan lamina dari bambu betung $(D$. asper) dengan ketebalan $5 \mathrm{~mm}$, lebar 20 $\mathrm{mm}$ dan panjang $3 \mathrm{~m}$ yang dilakukan oleh (Karyadi, Dewi, \& Soehardjono, 2014). Hal ini disebabkan kekuatan tarik bambu lebih besar dua kali dibandingkan kayu dan kekuatan tekan lebih baik $10 \%$ dibanding kayu (Mujiman, Priyosulistyo, Sulistyo, \& Prayitno, 2014). Pada tingkat rebung, bambu betung kaya akan nutrisi penting seperti asam amino, protein, karbohidrat, dan karbon masing-masing sebanyak 3,12; 3,52; 4,90; dan 3,20 g dalam $100 \mathrm{~g}$ berat basah (Chongtham, Bisht, \& Haorongbam, 2011).

Informasi ukuran dimensi batang bambu mengenai diameter ruas, panjang ruas, dan tebal dinding ruas sangat diperlukan terutama untuk keperluan konstruksi. Karakteristik fisik bambu beragam menurut jenis dan ukuran diameter (Sá Ribeiro, Sá Ribeiro, \& Miranda, 2017).

Informasi ukuran panjang, diameter, dan tebal dinding ruas bambu khususnya bambu betung masih terbatas. Oleh karena itu, pendekatan taper dibangun untuk memudahkan dalam identifikasi ukuran dimensi. Salah satu dimensi yang mudah diukur adalah umur dan diameter. Pendekatan taper terutama pada pohon dibangun dengan melihat hubungan diamater (dbh) dan tinggi terhadap biomassa (Chan, Takeda, Suzuki, \& Yamamoto, 2013). Bentuk dimensi batang seperti bambu belum banyak dilakukan. Pendekatan model akan membantu inventarisasi bambu dan menentukan jumlah bambu yang dikeluarkan dan hasil yang akan diperoleh, serta tindakan pengaturan hasil. Pengaturan hasil yang tepat, maka kesuburan tanah dapat dijaga. Selain itu, bambu betung memiliki kandungan bahan organik yang tinggi dibandingkan bambu yang lain sehingga berpotensi sebagai media tumbuh. Penelitian ini bertujuan untuk mengetahui dimensi pertumbuhan bambu betung berdasarkan umur yang terdiri atas panjang ruas, diameter ruas, dan tebal dinding ruas yang dinyatakan dalam model taper.

\section{METODOLOGI}

\section{A. Waktu dan Tempat Penelitian}

Pengumpulan data dilakukan di Hutan Penelitian Arcamanik yang terletak di Kabupaten Bandung dan kampus Badan Penelitian, Pengembangan dan Inovasi Kementerian Lingkungan Hidup dan Kehutanan di Bogor. Penelitian dilakukan pada Bulan Februari sampai Maret 2016. Hutan Penelitian (HP) Arcamanik terletak di Desa Arcamanik, Kecamatan Ujungberung, Kabupaten Bandung, Jawa Barat. Berada ketinggian tempat \pm 1.600 $m$ dari permukaan laut (dpl), curah hujan rata-rata $2.556 \mathrm{~mm} /$ tahun dan tipe iklim B menurut klasifikasi Schmidt dan Ferguson. Jenis tanah adalah asosiasi andosol coklat dan regosol coklat yang berasal dari bahan induk abu/pasir tufvolkan intermediet dan bertopografi volkan (Sutiyono \& Wardani, 2011).

\section{B. Metode Pengumpulan Data}

Pengumpulan data dilakukan dengan cara destruktif yakni menebang batang bambu dengan mempertimbangkan umur pada tiga rumpun berbeda. Pemilihan batang dilakukan secara purposive (sengaja) dengan pertimbangan umur dan arah rebah. Bambu betung yang digunakan berumur 3, 4, 5, 6 dan 7 tahun dengan masing-masing diambil tiga batang bambu pada dua rumpun bambu dan satu batang bambu dari rumpun ketiga, sehingga total jumlah contoh ada 
Lutfy Abdulah dan Sutiyono

45 batang. Batang yang dipilih diberi label umur dan nomor urut batang dan nomor urut rumpun. Penebangan dilakukan pada ruas pangkal menggunakan gergaji tangan atau golok. Setelah bambu ditebang, maka selanjutnya dilakukan pembersihan terhadap serasah daun dan ranting. Setiap ruas diberi label nomor ruas. Setelah itu, dilakukan pembagian batang dengan pertimbangan nomor ruas. Untuk sortimen 1 diambil dari nomor ruas $1-11$, sortimen 2 dari ruas nomor 12-22, sortimen 3 diambil dari ruas 23-33 dan sortimen 4 diambil dari nomor ruas 34-43 serta selebihnya merupakan sortimen 5 .

Setelah dilakukan pembagian sortimen dilakukan pengukuran panjang sortimen dengan menggunakan meteran dan mengukur diameter ruas dengan pita diameter. Batang bambu dibelah atas dua bagian untuk diukur tebal dinding ruas menggunakan caliper. Data hasil pengukuran kemudian disusun berdasarkan umur. Pengurutan sortimen ini menggunakan pendekatan cross-section. Yang dimaksud dengan cross-section adalah diasumsikan umur tersebut mewakili satu batang bambu. Data cross-section merupakan data berurutan waktu yang tidak diamati pada obyek yang sama. Penggunaan data ini dikarenakan pengamatan tidak dilakukan sepanjang periode penelitian, melainkan menggunakan batang bambu yang berbeda umur.

\section{Analisis Data}

1. Korelasi antara umur terhadap dimensi panjang ruas, diameter ruas dan tebal ruas bambu betung

Analisis dilakukan dengan memasukkan variabel umur, diameter ruas, panjang ruas, dan tebal dinding batang ruang sebagai variabel $\mathrm{X}$ (variabel bebas) dan variabel panjang ruas, diameter ruas, dan tebal dinding batang ruang sebagai $\mathrm{Y}$ (variabel tidak bebas). Analisis korelasi menggunakan uji Persson (Qudratullah, 2013).

$$
\left.\hat{\rho}=r=\frac{\sum_{i=1}^{n}\left(X_{i}-\bar{X}\right)(Y-\bar{Y})}{\sqrt{\sum_{i=1}^{n}\left(X_{i}-\bar{X}\right)^{2}} \sqrt{\sum_{i=1}^{n}\left(Y_{i}-\bar{Y}\right)^{2}}} \ldots \ldots \ldots 1\right)
$$

\section{Model taper bambu betung}

Pendekatan yang digunakan adalah pendekatan simultaneous-equation untuk menduga diameter ruas. Untuk tebal dinding merupakan fungsi dari diameter ruas. Dengan demikian, pendekatan dalam membangun model tebal dinding ruas bambu yakni multi-equation recursive. Pemilihan model terbaik berdasarkan koefisien determinasi $\left(\mathrm{R}^{2}\right)$ dan simpangan baku. Data yang digunakan untuk penyusunan model sebanyak 23 batang sampel. Selanjutnya data dianalisis dengan bantuan program Ms. Excel, Minitab, dan Curve Expert.

\section{Uji validitas model dengan uji statistik Chi-square}

Untuk melakukan pengujian model, disiapkan 11 batang sampel yang berbeda dari data pembangunan model. Validasi dilakukan dengan menggunakan uji Chisquare dengan rumus:

$\chi_{\text {hitung }}=\sum_{i=1}^{i=n-1} \frac{\left(O_{i}-E_{i}\right)}{E_{i}}$

Dimana:

$\mathrm{O}_{\mathrm{i}}=$ Data hasil pengukuran lapangan (Field measurement data)

$\mathrm{E}_{\mathrm{i}}=$ Data model (Model data)

Hipotesa:

$\mathrm{H}_{0}: \quad x_{\text {hitung }} \leq \mathcal{X}_{\text {Tabel}}$, tidak ada perbedaan data model dengan data lapangan (there is no difference in model data with field data)

$\mathrm{H}_{1}: \quad X_{\text {hitung }} \geq \mathcal{X}_{\text {Tabel, }}$, terdapat perbedaan data model dengan data lapangan (there is no difference in model data with field data) 


\section{HASIL DAN PEMBAHASAN}

A. Hasil

1. Korelasi antara umur terhadap dimensi panjang ruas, diameter ruas, dan tebal ruas bambu petung

Umur bambu memiliki korelasi yang nyata dengan panjang dan diameter ruas bambu, meski ukuran korelasi sangat rendah. Sementara variabel panjang memiliki korelasi yang erat dengan diameter ruas bambu. Sebaliknya diameter ruas bambu memiliki korelasi dengan panjang, namun koefisien korelasinya sangat rendah. Uji korelasi antara umur dengan panjang ruas, diameter ruas, dan tebal dinding disajikan pada Tabel 1.

Berdasarkan Tabel 1 terlihat bahwa jumlah contoh yang dibuat korelasinya sebanyak 1420 individu. Korelasi nyata terlihat antara umur dengan panjang dan diameter ruas bambu, namun korelasi antara umur dengan tebal dinding batang bambu tidak nyata. Meski hubungan korelasi antara umur dan panjang dan diameter ruas nyata namun koefisien korelasi sangat kecil. Hal ini disebabkan oleh jangkauan data maksimum ke minimum sangat lebar terhadap nilai tengah. Hal ini dapat dilihat pada diagram boxplot (Gambar 1).

Rata-rata panjang, diameter, dan tebal dinding ruas berada pada satu garis yang sejajar, meski pada umur yang berbeda. Pergeseran nilai rata-rata ketika bertambahnya umur dari 3 tahun ke-7 tahun sangat sempit dengan variasi data yang lebar. Hal ini dapat dilihat pada Gambar 1 bahwa terdapat jarak dari nilai rata-rata ke batas luar kotak. Hal ini mengindikasikan variasi data terhadap nilai rata-rata yang tidak normal.

Adapun uji normalitas terhadap variabel panjang, diameter, dan tebal dinding ruas disajikan pada Gambar 2. Hasil uji menunjukkan bahwa p-value lebih kecil dari $\alpha=5 \%$. Hal ini mengindikasikan bahwa panjang, diameter, dan tebal dinding ruas bambu tidak berdistribusi normal. Kondisi ini menunjukkan bahwa bentuk model penduga berbentuk regresi berganda dan bukan regresi sederhana (Qudratullah, 2013).

Tabel (Table) 1. Uji korelasi umur terhadap panjang ruas, diameter ruas dan tebal dinding ruas (The correlation test of age to node length, node diameter and wallnode thick)

\begin{tabular}{llrrrr}
\hline & & $\begin{array}{c}\text { Umur } \\
\text { (Age) }\end{array}$ & $\begin{array}{c}\text { Panjang } \\
\text { (Length) }\end{array}$ & $\begin{array}{c}\text { Diameter } \\
\text { (Diameter })\end{array}$ & $\begin{array}{r}\text { Tebal (wall-node } \\
\text { thick) }\end{array}$ \\
\hline Umur (Age) $)$ & Pearson Correlation & 1 & $0,080^{* * *}$ & $0,096^{* *}$ & 0,023 \\
& Sig. (2-tailed) & & 0,003 & 0,000 & 0,393 \\
& $\mathrm{~N}$ & 1420 & 1420 & 1419 & 1420 \\
Panjang & Pearson Correlation & $0,080^{* *}$ & 1 & $0,589^{* *}$ & $0,095^{* *}$ \\
(Length) & Sig. (2-tailed) & 0,003 & & 0,000 & 0,000 \\
& $\mathrm{~N}$ & 1420 & 1420 & 1419 & 1420 \\
Diameter & Pearson Correlation &, $096^{* *}$ &, $589^{* *}$ & 1 &, $779^{* *}$ \\
(Diameter) & Sig. (2-tailed) & 0,000 & 0,000 & & 0,000 \\
& $\mathrm{~N}$ & 1419 & 1419 & 1419 & 1419 \\
Tebal (wall- & Pearson Correlation & 0,023 & $0,095^{* *}$ & $0,779^{* * *}$ & 1 \\
node thick) & Sig. (2-tailed) &, 393 &, 000 &, 000 & 1420 \\
& $\mathrm{~N}$ & 1420 & 1420 & 1419 & \\
\hline
\end{tabular}

**. Correlation is significant at the 0.01 level (2-tailed). 


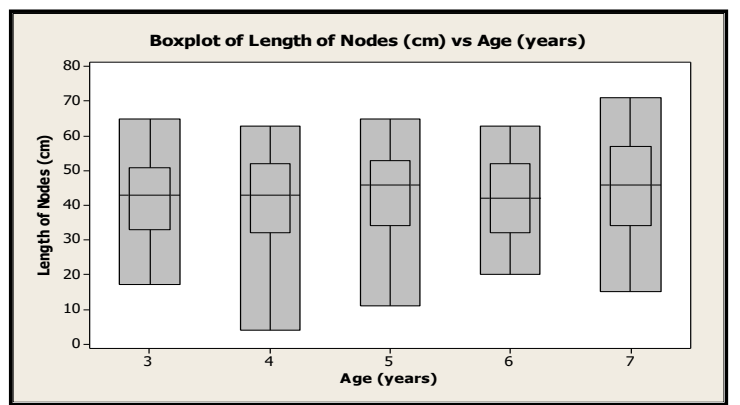

(a)

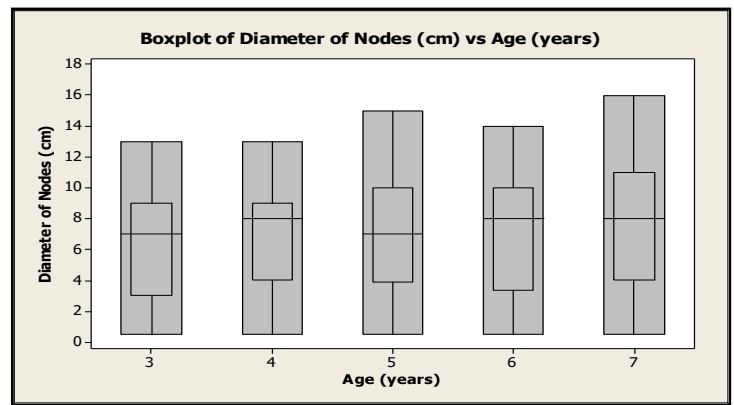

(b)

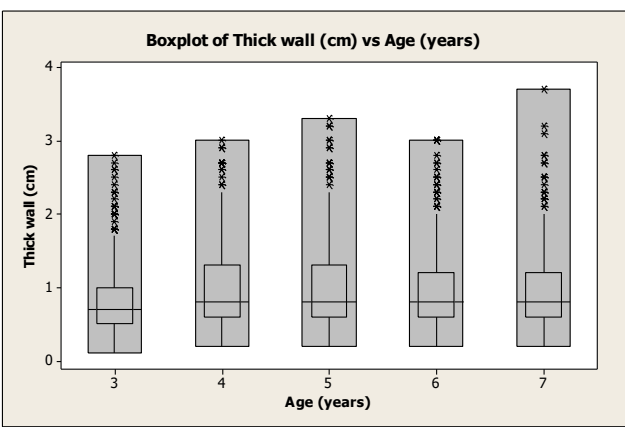

(c)

Gambar (Figure) 1. Diagram boxplot panjang ruas (a), panjang ruas (b) diameter ruas, (c) tebal dinding ruas (The boxplot diagram of node length, node diameter and wall-node thick)

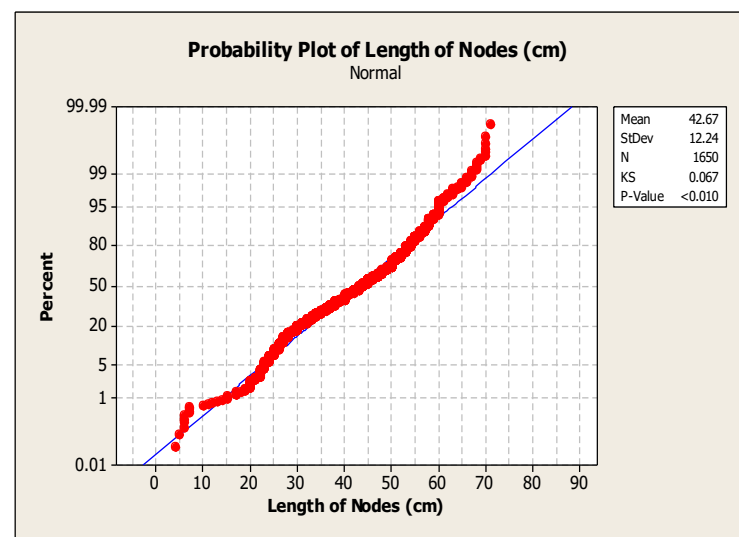

(a)

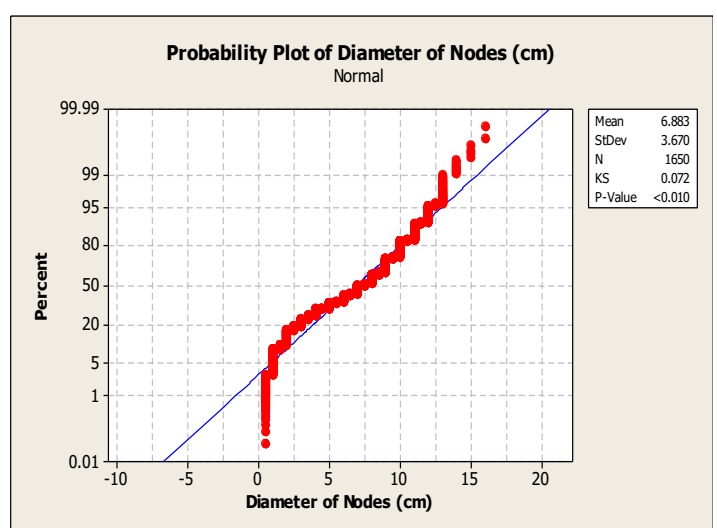

(b)

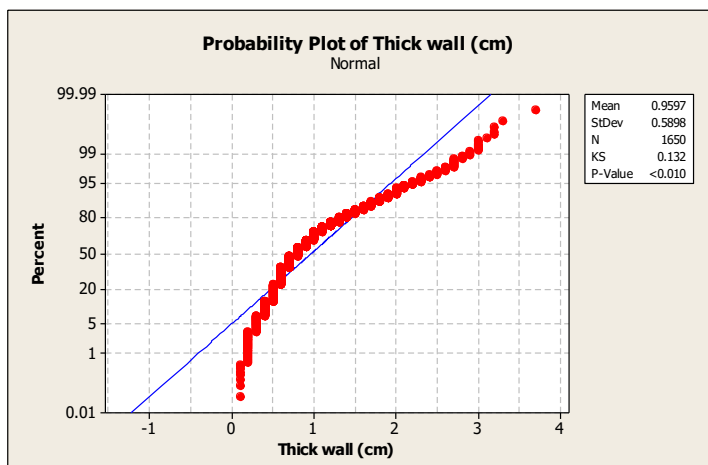

(c)

Gambar (Figure) 2. Uji normalitas terhadap variable panjang (a), diameter (b) dan tebal dinding ruas (c). (The normality test of node length, node diameter and wall-node thick) 


\section{Model taper bambu betung}

Pada umumnya, model taper digunakan untuk menduga hasil seluruh batang atau bagian dari batang. Terdapat tiga kombinasi dalam membangun model taper yakni: (1) model persamaan tunggal, dimana setiap diameter yang diduga dengan suatu persamaan dan tidak dapat diduga dengan persamaan yang lain; (2) model multi-equation recursive, yakni suatu model yang digunakan untuk menduga diameter dan hasilnya kemudian disubstitusikan ke model yang lain; (3) Simultaneous-equation model, yakni suatu diameter yang diduga dengan sebuah persamaan yang dibangun dari semua diameter yang terdapat dalam suatu batang.

Berdasarkan klasifikasi di atas, maka penelitian ini menggunakan pendekatan simultaneous-equation model, dimana model penduga diameter ruas diduga dari diameter pada ruas ke-4, panjang ruas dan tinggi total bambu. Adapun model terbaik yang dihasilkan adalah sebagai berikut:

$$
\mathrm{d}_{(\mathrm{h}, \mathrm{i})}=-6,9274-11,9060(\mathrm{~h} / \mathrm{H})^{2}+7,5307
$$

Keterangan:

$\mathrm{d}_{\mathrm{h}, \mathrm{i}}=$ Diameter ruas ke-i (Diameter of segment to-i) $(\mathrm{cm})$

$\mathrm{h} \quad=$ Panjang ruas (Section length) $(\mathrm{m})$

$\mathrm{H}=$ Panjang total (Total length) $(\mathrm{m})$

$\mathrm{D}_{4}=$ Diameter ruas ke-4 (Diameter of $4^{\text {th }}$ segment)

Berdasarkan model di atas, dapat diketahui bahwa diameter ruas merupakan fungsi rasio antara panjang ruas dengan panjang total dan diameter pada ruas ke-4. Diameter ruas ke-4 menjadi variabel model dengan pertimbangan bahwa berdasarkan pengamatan lapangan dan hasil diskusi menunjukkan petani biasanya menebang batang bambu pada ruas ke-4 atau dapat dikatakan ruas ke-1 sampai dengan ruas ke-4 menjadi tunggak. Koefisien determinasi $\left(\mathrm{R}^{2}\right)$ sebesar $92 \%$ dan standar deviasi sebesar $0,81 \mathrm{~cm}$.

\section{Model taper tebal dinding bambu betung}

Tebal dinding ruas bambu tidak memiliki hubungan dengan umur bambu. Ukuran tebal dinding antara $0,1 \mathrm{~cm}$ sampai dengan $3,7 \mathrm{~cm}$, dengan pola ukuran tebal dinding mengikuti ukuran diameter ruas.

Tabel (Table) 2. Analisis ragam penduga diameter ruas (Analisis variance of node diameter model)

\begin{tabular}{lrrr}
\hline \multicolumn{1}{c}{ Predictor } & Coefissien & Standard Error & $\mathrm{P}_{\text {value }}$ \\
\hline Constant & $-6,9274$ & 0,3451 & 0,0000 \\
$(\mathrm{~h} / \mathrm{H})^{2}$ & $-11,9060$ & 0,1294 & 0,0000 \\
$\mathrm{Ln}\left(\mathrm{d}_{4}\right)$ & 7,5307 & 0,1472 & 0,0000 \\
$\mathrm{~S}=0,80981$ & $\mathrm{R}^{2}=91,9 \%$ & $\mathrm{R}_{(\mathrm{adj})}^{2}=91,9 \%$ & \\
\hline
\end{tabular}

Tabel (Table) 3. Analisis ragam tebal dinding (Analysis variance of wall thick)

\begin{tabular}{lrrr}
\hline \multicolumn{1}{c}{ Predictor } & Coefissien & Standard Error & $\mathrm{P}_{\text {-value }}$ \\
\hline Constant & 0,32447 & 0,09985 & 0,001 \\
$\mathrm{Ni}$ & $-0,00766$ & 0,00099 & 0,000 \\
$\mathrm{Ln}(\mathrm{h})$ & $-0,36565$ & 0,01290 & 0,000 \\
$\mathrm{Ln}(\mathrm{D} 4)$ & 0,66122 & 0,04284 & 0,000 \\
$\mathrm{~S}=0,2567$ & $\mathrm{R}^{2}=80,1 \%$ & $\mathrm{R}_{(\mathrm{adj})}^{2}=80,0 \%$ & \\
\hline
\end{tabular}




\section{Pengaruh Penyimpanan dan Waktu Penetasan Telur Terhadap Kualitas Bibit Ulat Sutra dan Kualitas Kokon Bombyx Mori L.}

Lincah Andadari dan Kuntadi

\section{Validasi model taper}

a. Hasil validasi model penduga diameter batang bambu betung

Validasi model merupakan perbandingan antara data model dengan data lapangan, dengan tujuan untuk mengetahui tingkat kesamaan antara data hasil model dengan data lain yang diambil di lapangan. Adapun hasil uji validasi disajikan pada Tabel 4.

Berdasarkan hasil uji di atas terlihat bahwa Chi-hitung sebesar -10,64, sementara Chi-tabel sebesar 628,75. Dengan demikian bahwa tidak cukup bukti untuk menolak $\mathrm{H}_{0}$ atau dapat dikatakan tidak ada perbedaan antara data pengukuran diameter ruas dengan model diameter ruas bambu. Hal ini berarti bahwa model penduga diameter ruas bambu betung valid.

\section{b. Hasil validitas model penduga tebal dinding ruas \\ Validasi model merupakan per- bandingan antara data model dengan data}

lapangan, dengan tujuan untuk mengetahui tingkat kesamaan antara data hasil model dengan data lain yang diambil di lapangan. Adapun hasil uji validasi disajikan pada Tabel 5.

Berdasarkan hasil uji di atas terlihat bahwa Chi-hitung sebesar 28,92, sementara Chi-tabel sebesar 628,75. Dengan demikian bahwa tidak cukup bukti untuk menolak $\mathrm{H}_{0}$ atau dapat dikatakan tidak ada perbedaan antara data pengukuran tebal dinding ruas dengan model penduga tebal dinding ruas bambu. Hal ini berarti bahwa model penduga tebal dinding ruas bambu betung valid.

\section{B. Pembahasan}

Bambu tumbuh sekali dalam satu tahun, dan di tahun berikutnya tidak terjadi pertumbuhan pada batang yang sama (Tran, 2010). Tunas tepi rimpang akan berdiferensiasi menjadi tunas-tunas yang kemudian akan berkembang menjadi batang baru. Pemahaman ini mendorong bahwa terdapat keunikan model penduga pertumbuhan bambu.

Tabel (Table) 4. Uji Validasi model penduga diameter ruas dengan uji Chi-square (The validity test of node diameter model with paired Chi-square statistic)

\begin{tabular}{ccccc}
\hline Data & $\begin{array}{c}\text { Jumlah sampel (Number } \\
\text { of sample) }\end{array}$ & Mean & StDev & SE Mean \\
\hline Lapangan (Filed) & 572 & 6,74 & 3,78 & 0,16 \\
Model & 572 & 7,03 & 3,69 & 0,15 \\
\hline Keterangan (Remarks): & Difference $=$ mu (lapangan/field) - mu (model); Chi-hitung = -10,64 Chi-table = \\
& 628,75 DF $=572$
\end{tabular}

Tabel (Table) 5. Uji validasi model tebal dinding dengan uji Chi-square (The validity test of wall thick with paired Chi-square statistic)

\begin{tabular}{lcccc}
\hline Data & $\begin{array}{c}\text { Jumlah sampel (Number } \\
\text { of sample) }\end{array}$ & Mean & StDev & SE Mean \\
\hline Lapangan (Filed) & 572 & 6,74 & 3,78 & 0,16 \\
Model & 572 & 7,03 & 3,69 & 0,15 \\
\hline Keterangan (Remarks): & Difference $=$ mu (Tebal_lapangan/field) - mu (Tebal_model); Chi-value = 28,92 Chi- \\
& table $=628,75 \mathrm{DF}=572$
\end{tabular}

Hasil pengukuran menunjukkan bahwa panjang ruas bambu akan mencapai selang terpanjang di tengah batang bambu pada ruas ke-11 sampai 
dengan 30. Sementara diameter ruas terbesar berada di pangkal batang bambu dan semakin ke ujung akan semakin kecil. Hal yang sama terjadi pada tebal dinding bambu. Hal ini mengindikasikan bahwa diameter berkorelasi dengan tebal dinding ruas bambu, dan hal ini teruji secara statistik.

Uji korelasi di atas menunjukkan bahwa hubungan antara umur dengan panjang dan diameter ruas bambu nyata dengan koefisien korelasi yang sangat rendah. Hal ini bisa terjadi karena jenis data yang digunakan cross-section. Data cross-section merupakan data berurutan waktu yang tidak diamati pada obyek yang sama. Penggunaan data ini dikarenakan pengamatan tidak dilakukan sepanjang periode penelitian, melainkan menggunakan batang bambu yang berbeda umur. Korelasi Pearson merupakan sebuah angka koefisien yang dipengaruhi oleh nilai-nilai ekstrim, diduga berada di atas atau dibawah nilai rata-rata. Untuk itu tidak tepat jika salah satu atau kedua variabel yang dibandingkan tidak terdistribusi secara normal (Mukaka, 2012).

Hasil uji korelasi antara umur dengan tebal dinding menyatakan tidak ada hubungan linier. Biasanya tebal dinding ruas dipengaruhi oleh tingkat kesuburan lahan (Nath, Das, Chandra, \& Sinha, 2009). Jenis tanah di lokasi penelitian adalah andosol. Jenis tanah ini terkenal subur karena berasal dari erupsi gunung berapi (Sukarman \& Dariah, 2014). Kesuburan bambu membantu pertumbuhan rhizoma sebagai bakal batang bambu. Pengaturan hasil berupa menjaga kerapatan rumpun bambu dengan memanfaatkan rebung sebagai bahan makanan akan membantu pertumbuhan diameter bambu yang baik. Selain itu, kandungan bahan organik rebung dan bahan organik dalam tanah di bawah tegakan bambu betung sangat tinggi sehingga menjamin tersedianya unsur hara bagi pertumbuhan biomassa batang bambu tersebut (Akinlabi, Anane-Fenin, \& Akwada, 2017).

Perilaku pertumbuhan biomassa yang demikian digambarkan dengan bentuk persamaan eksponensial (Yuen et al., 2017). Pertumbuhan diameter batang akan memberikan pertumbuhan membelok ke arah positif berbentuk eksponensial. Bentuk persamaan nonlinier sebagaimana dihasilkan dalam penelitian ini serupa dengan bentuk pendugaan pertumbuhan biomassa terutama bambu. Persamaan non linier dapat menggambarkan perilaku pertumbuhan karena umur meski diketahui, tetapi bambu hanya tumbuh dalam satu musim penghujan. Perilaku iklim berasosiasi dengan pertumbuhan tinggi, tingkat kesuburan, dan kepadatan rumpun.

Pengaturan hasil pertumbuhan bambu betung sangat membutuhkan informasi pengaruh umur terhadap hasil pemanenan. Bambu tumbuh cepat, dapat mencapai $30 \mathrm{~m}$ dalam 1 tahun (Sharma, Gatoo, Bock, Mulligan, \& Ramage., 2014) dan setelah itu akan mencapai struktur struktur optimal sampai umur 3-5 tahun (Sharma et al., 2014). Terdapat pengaruh nyata linier umur terhadap parameter panjang dan diameter, namun keeratan hubungannya sangat rendah. Hal ini disebabkan oleh sebaran nilai sisaan panjang ruas, diameter ruas, dan tebal dinding ruas (Xi) pada suatu umur terhadap nilai rata-rata masing-masing umur masih sangat lebar. Sebagaimana dijelaskan oleh Qudratullah (2013) bahwa korelasi Pearson (product moment pearson) merupakan analisis keeratan hubungan linier (garis lurus) antara dua peubah yang umumnya digunakan pada analisis statistic parametric dan merupakan rasio antara kovarian variabel $\mathrm{X}$ dan $\mathrm{Y}$ terhadap akar kuadrat dari variabel $\mathrm{X}$ dikalikan akar kuadrat dari variabel Y. Di lain pihak, menegaskan bahwa pertumbuhan biomassa bambu sangat beragam menurut jenis dan lokasi 
(Ly, Pillot, Lamballe, \& de Neergaard, 2012).Yuen et al.(2017) justru melihat bahwa keragaman dapat terjadi karena belum adanya standar terkait pendugaan karbon dan pertumbuhan bambu.

Model penduga diameter ruas merupakan fungsi dari diameter ruas terpilih (ruas ke-4) dengan rasio panjang ruas terhadap panjang total. Bentuk fungsi dalam logaritma natural. Penggunaan logaritma natural dari kedua variabel ini menunjukkan bahwa bila diameter ruas ke-4 besar, maka kemungkinan diameter ruas akan besar, sampai dengan rasio antar panjang ruas dan panjang total batang yang besar. Semakin besar rasio panjang ruas terhadap panjang total, maka ukuran diameter ruas akan semakin kecil. Panjang bambu di lokasi penelitian mencapai 19-25 m, dengan diameter pangkal antara 9-14 cm. Karateristik bambu betung ini lebih besar dibandingkan bambu betung di India (Garima, Bhardwaj, \& Devi, 2017). Panjang bambu betung di India hanya mencapai $6,35 \mathrm{~m}$ dan diameter $3,3 \mathrm{~cm}$.

Hasil penelitian ini sangat bermanfaat untuk menentukan hasil panen bambu dan tindakan pengelolaan berkelanjutan. Variasi produk bambu akan meningkatkan nilai ekonomi bambu tersebut. Untuk tujuan konstruksi berupa lamina, ukuran komersil yang digunakan adalah $244 \mathrm{~cm}$ x $122 \mathrm{~cm}$ x 1,9 cm (Sharma et al., 2015). Pada ukuran komersil seperti ini, maka semakin besar ukuran diameter dan angka bentuk silinder batang bambu akan meningkatkan rendemen bambu. Semakin silinder batang bambu dan semakin panjang ukuran ruas serta diikuti dengan ukuran diameter serta tebal dinding yang besar, maka rendemen batang bambu betung untuk lamina akan semakin baik. Hasil penelitian Awalluddin, Ariffin, Osman, Hussin,Ismail, Lee, Shukor, \& Lim (2017) menyatakan bahwa terdapat perbedaan karakteristik mekanis pada bambu berdasarkan letaknya. Rata-rata kekuatan bambu di bagian ujung lebih baik dibandingkan di pangkal yakni 68,05 $\mathrm{N} / \mathrm{mm}^{2}$ dan $60,23 \mathrm{~N} / \mathrm{mm}^{2}$. Sebaliknya, kandungan uap air lebih besar dipangkal dibandingkan di ujung $(18,44 \%$ dan $15,85 \%)$.

\section{KESIMPULAN DAN SARAN}

\section{A. Kesimpulan}

Hasil penelitian ini menunjukkan bahwa tidak terdapat hubungan yang nyata antara umur dengan parameter diameter ruas, tebal dinding, dan panjang ruas. Namun, terdapat hubungan antara panjang total dan panjang ruas terhadap diameter ruas. Bentuk model taper diameter ruas adalah $\mathrm{d}_{\mathrm{h}, \mathrm{i}}=-6,9274$ $11,9060(\mathrm{~h} / \mathrm{H})^{2}+7,5307 \ln \left(\mathrm{D}_{4}\right) ; \mathrm{d}_{\mathrm{h}, \mathrm{i}}=-$ $6,9274-11,9060(\mathrm{~h} / \mathrm{H})^{2}+7,5307 \ln \left(\mathrm{D}_{4}\right)$ Bentuk hubungan nyata lainnya adalah antara tebal dinding bambu setiap ruas terhadap nomor urut ruas, diameter ruas, dan panjang ruas, yakni: $T_{i}=0,324-$ $0,00766 n_{i}-0,366 \ln (\mathrm{h})+0,661 \ln \left(\mathrm{D}_{4}\right)$; $\mathrm{T}_{\mathrm{i}}=0,324-0,00766 \mathrm{n}_{\mathrm{i}}-0,366 \ln (\mathrm{h})+$ $0,661 \ln \left(\mathrm{D}_{4}\right)$.

\section{B. Saran}

Penelitian ini telah menghasilkan sebuah perangkat pendugaan karakteristik hasil pertumbuhan dari bambu yang unik. Untuk itu, model ini perlu diuji di beberapa lokasi untuk dibuatkan tabel volume bambu betung.

\section{UCAPAN TERIMA KASIH}

Ucapan terima kasih penulis sampaikan kepada Manajemen PT Sampoerna Agro yang telah membiayai penelitian ini, Bapak Ir. Harbagung yang telah berdikusi dalam membangun model dan rekan-rekan di hutan penelitian Arcamanik yang telah mendampingi dan membantu pelaksanaan penelitian. 


\section{DAFTAR PUSTAKA}

Akinlabi, E.T., Anane-Fenin, K., \& Akwada, D.R. (2017). Bamboo: Multipurpose plant. Springer International Publishing. https://doi.org/10.1007/978-3-31956808-9

Awalluddin, D., Ariffin, M.A., Osman, M.H., Hussin, M.W., Ismail, M.A., Lee, H.S., \& Abdul Shukor Lim, N.H. (2017). Mechanical properties of different bamboo species. MATEC Web of Conferences, 138, 1-10. https://doi.org/10.1051/matecconf/ 201713801024

Chan, N., Takeda, S., Suzuki, R., \& Yamamoto, S. (2013). Establishment of allometric models and estimation of biomass recovery of swidden cultivation fallows in mixed deciduous forests of the Bago Mountains, Myanmar. Forest Ecology and Management, 304, 427436.

https://doi.org/10.1016/j.foreco.2013. 05.038

Chongtham, N., Bisht, M.S., \& Haorongbam, S. (2011). Nutritional properties of bamboo shoots: Potential and Prospects for Utilization as a Health Food. Comprehensive Reviews in Food Science and Food Safety, 10(3), 153-168. https://doi.org/10.1111/j.15414337.2011.00147.x

Garima, Bhardwaj, D., \& Devi, M. (2017). Growth behaviour of bamboo species in bamboo-based agroforestry system in mid-hill sub-humid conditions of Himachal Pradesh , India. International Journal of Farm Sciences, 7(2), 63-66.

Karyadi, Dewi, S.M., \& Soehardjono, A. (2014). A comparison of shear strength of box-section beam made of sliced-laminated dendrocalamusasper under torsion and transversal load.
Procedia Engineering, 95(Scescm), 38-42. https://doi.org/10.1016/ j.proeng.2014.12.163

Ly, P., Pillot, D., Lamballe, P., \& de Neergaard, A. (2012). Evaluation of bamboo as an alternative cropping strategy in the northern central upland of Vietnam: Above-ground carbon fixing capacity, accumulation of soil organic carbon, and socio-economic aspects. Agriculture, Ecosystems and Environment, 149, 80-90. https://doi.org/10.1016/ j.agee.2011.12.013

Muchiri, M.N., \& Muga, M.O. (2013). A preliminary yield model for natural Yushania alpina bamboo in Kenya. Journal of Natural Sciences Research, 3(10), 77-84. Retrieved from http://www.iiste.org/Journals/index.p $\mathrm{hp} / \mathrm{JNSR} /$ article/view/7651/8078

Mujiman, Priyosulistyo, H., Sulistyo, D., \& Prayitno, T.A. (2014). Influence of shape and dimensions of lamina on shear and bending strength of vertically glue laminated bamboo beam. In Procedia Engineering, 95, 22-30. https://doi.org/10.1016/ j.proeng.2014.12.161

Mukaka, M.M. (2012). A guide to appropriate use of Correlation coefficient in medical research. Malawi Medical Journal, 24(3), 6971. https://doi.org/10.1016/ j.cmpb.2016.01.020

Nath, S., Das, R., Chandra, R., \& Sinha, A. (2009). Bamboo Based Agroforestry for Marginal Lands with Special Reference to Productivity, Market Trend and Economy. Jharkhand. Retrieved from http://citeseerx.ist.psu.edu/viewdoc/d ownload?doi=10.1.1.564.1866\&rep $=$ rep $1 \&$ type $=$ pdf

Qudratullah, M.F. (2013). Analisis Regresi Terapan: teori, Contoh Kasus dan Aplikasi Dengan SPSS. 
Lutfy Abdulah dan Sutiyono

Yogyakarta: Penerbit ANDI. https://doi.org/

extraordinarynad.lecture.ub.ac.id/file s/2012/12/Analisis-Regresi.docx

Sá Ribeiro, R.A., Sá Ribeiro, M.G., \& Miranda, I.P.A. (2017). Bending strength and nondestructive evaluation of structural bamboo. Construction and Building Materials, 146 , 38-42. https://doi.org/10.1016/j.conbuildmat .2017.04.074

Salam, K., \& Pongen, Z. (2008). Hand Book on Bamboo. (S.K. Sharma, Ed.). New Delhi: National bamboo Mission Ministry of Agriculture, Government India dan Cane and Bamboo Technology Centre.

Sharma, B., Gatoo, A., Bock, M., Mulligan, H., \& Ramage, M. (2014). Engineered bamboo: state of the art. In Proceedings of Instituion of Civil Engineers, 1-11.

Sharma, B., Gatoo, A., Bock, M., \& Ramage, M. (2015). Enginered bamboo for structural applications. Journal of Construction and Building
Materials, 81, 66-73.

Sukarman, \& Dariah, A. (2014). Tanah Andosol di Indonesia. Bogor: Balai Besar Penelitian dan Pengembangan Sumberdaya Lahan Pertanian.

Sutiyono, \& Wardani, M. (2011). Pertumbuhan Awal Tanaman Bambu Tutul (Bambusa maculata Widjaja) di Stasiun Penelitian Hutan Arcamanik, Bandung. In Konservasi Tumbuhan Tropika: Kondisi Terkini dan Tantangan ke Depan. Bogor: UPT Balai Konservasi Tumbuhan Kebun Raya Cibodas - LIPI.

Tran, V.H. (2010). Growth and quality of indigenous bamboo species in the mountainous regions of Northern Vietnam, (March), 1-135.

Yuen, J.Q., Fung, T., \& Ziegler, A.D. (2017). Carbon stocks in bamboo ecosystems worldwide: Estimates and uncertainties. Forest Ecology and Management, 393, 113-138. https://doi.org/10.1016/j.foreco.2017. 01.017 